\title{
Engendering Democracy
}

VaLENTINe MoghadaM

Sociology and Women's Studies, Purdue University, West Lafayette, Ind.;

e-mail: vmoghada@purdue.edu

doi:10.1017/S002074381100047X

The year 2011 will forever be known as the year of mass protests for regime change and democratization in the Middle East and North Africa (MENA). Opinions on causes and outcomes have focused on the role of young people, the demands of "the Arab street," and the possible transition to a liberal, Islamist, or coalition type of governance. Middle East specialists have long been aware of the problems of authoritarian regimes, widening inequalities, high rates of youth unemployment, deteriorating infrastructure and public services, and rising prices attenuated only by subsidies. But something has been missing from recent discussions and analyses. Let us pose it in the form of a number of (socialist-feminist) questions. We have seen that "the Arab street" is not exclusively masculine, but what kind of democratic governance can women's rights groups expect? To what extent will Tunisian women shape the democratic transition and the building of new institutions? In Egypt, will an outcome be - to use a phrase coined by East European feminists in the early 1990s - a "male democracy"? How can a democratic transition benefit working women and the poor?

Traditional approaches to democratization found a strong relationship between economic development and democracy. Today, feminist social scientists argue that a polity is not fully democratic when there is inadequate representation of women. Yet many commentators and policymakers nonetheless address democratization without taking women and gender issues into account. Here I make a fourfold argument. First, there is a positive relationship between women's participation and rights, on the one hand, and the building of democracy on the other. Examples from Latin America, South Africa, and Northern Ireland show that women's participation was a key element in the successful transitions and that outcomes could be advantageous to women's interests. Second, democracy is assumed by many commentators to serve women well, but the historical record shows that democratic transitions do not always bring about women's participation and rights. We need to take seriously the "democracy paradox," or the gender-based democracy deficit-that is, the marginalization of women from the political process in a democratic polity, or the dangers posed to gender equality by the opening up of political space to fundamentalist forces. Third, the longstanding exclusion of women from political processes in the MENA is a key factor in why the region has been a comparative "laggard" in democratization's third wave. Attention to women's participation and rights, including a strong presence in political parties, could speed up the transition. Fourth, the mass social protests in the MENA are as much a call for social justice as for civil and political rights. Attention to social and gender equality will ensure a more stable democracy. 